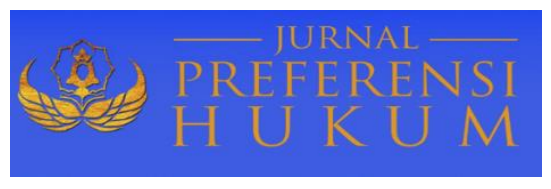

Jurnal Preferensi Hukum | ISSN: 2746-5039

Vol. 2, No. 1 - Februari 2021, Hal. 172-176| Available online at https://www.ejournal.warmadewa.ac.id/index.php/juprehum

DOI: https://doi.org/10.22225/jph.2.1.2814.172-176

\title{
PERTANGGUNGJAWABAN PIDANA TERHADAP PENGANIAYAAN YANG DILAKUKAN ANAK KEPADA ORANG TUA DITINJAU DALAM PERSPEKTIF HAM
}

\author{
I Wayan Ogi Wiryawan, I Made Minggu Widyantara, Luh Putu Suryani \\ Fakultas Hukum Universitas Warmadewa, Denpasar-Bali, Indonesia \\ ogihendra1717@gmail.com,mademinggu21@gmail.com, suryani.@fhwjurnal@gmail.com
}

\begin{abstract}
Abstrak
Saat ini, penganiayaan kepada orang tua yang dilakukan oleh anak, sering terjadi dikalangan masyarakat yang biasa disebut dengan kekerasan anak terhadap orang tua. Anak menjadi jahat disebabkan oleh dua faktor yaitu faktor internal dan faktor eksternal sehingga nekat berbuat perilaku tidak berperikemanusiaan terhadap orangtuannya sendiri. Kasus ini juga merupakan pelanggaran Hak Asisi Manusia yang wajib ditegakan. Namun, seorang anak tidak dapat dipidana karena maish dibawah umur. Penelitian ini bertujuan untuk menganalisis pengaturan pemidanaan terhadap anak dibawah umur yang melakukan tindak pidana kepada orang tua dan menjelaskan sanksi pemidanaan yang diberikan terhadap seorang anak yang melakukan tindak pidana penganiayaan. Metode penelitian yang digunakan adalah penelitian hukum normatif dengan menggunaan pendekatan perundang-undangan dan juga pendekatan konseptual. Data yang digunakan adalah data primer yaitu aturan hukum yang diurut secara sistematik terdiri dari perundang-undangan sedangkan data sekunder yaitu terdiri dari buku-buku, teks, prinsip-prinsip dan tulisan tentang hukum yang terkait pengaaniayaan. Terdapat juga berupa tulisan dalam penelitian ini. Hasil penelitian ini menunjukan bahwa anak tetap dapat dikenakan sanksi pidana namun juga bisa dikenakan sanksi berupa sanksi pembinaan oleh instansi terkait. Anak dalam kasus ini yang melakukan tindak pidana penganiayaan adalah seorang anak dibawah umur, pemidanaannya pun berbeda dengan pemidanaan biasa dimana pemidanaan anak bertujuan membina anak dan bukan berfokus pada efek jera bagi pelaku kejahatan.
\end{abstract}

Kata Kunci: Penganiayaan; Pemidanaan; Anak; Orang Tua; HAM.

\begin{abstract}
At present, abuse of parents by children, often occurs in the community, which is commonly referred to as child abuse against parents. Children become evil due to two factors, namely internal factors and external factors so that they are reckless to commit inhumane behavior towards their own parents. This case is also a violation of human rights that must be enforced. However, a child cannot be convicted of being underage. This study aims to analyze the criminal arrangements for minors who commit crimes against parents and explain the criminal sanctions given to a child who commits a criminal act of maltreatment. The research method used is normative legal research using a statutory approach as well as a conceptual approach. The data used are primary data, namely legal rules sorted systematically consisting of legislation, while secondary data consists of books, texts, principles and writings on laws related to persecution. There is also a form of writing in this research. The results of this study indicate that children can still be subject to criminal sanctions but can also be subject to sanctions in the form of fostering sanctions by related agencies. The child in this case who commits the crime of abuse is a minor, the punishment is different from ordinary punishment where child punishment is aimed at fostering the child and not focusing on the deterrent effect of the criminal.
\end{abstract}

Keywords: Persecution; Criminalization; Child; Parents; HAM.

\section{PENDAHULUAN}

Negara hukum pada dasarnya bertujuan untuk memberikan perlindungan hukum bagi rakyatnya tanpa pilih bulu. Menurut, Harahap (2002), perlindungan hukum yang dimaksud yaitu perlindungan terhadap serangkaian tindakan pemerintah yang berlandaskan pada prinsip hak asasi manusia dan prinsip negara hukum. Arus globalisasi yang telah terjadi selain menghadirkan berbagai efek positif terhadap sendi-sendi kehidupan juga menimbulkan beberapa efek negatif yang sangat merugikan, menimbulkan berbagai macam bentuk masalah turut andil mempengaruhi hampir seluruh aspek kehidupan manusia meliputi bidang budaya, sosial, politik, 
ekonomi, ilmu pengetahuan dan teknologi sehingga terdapat suatu perubahan-perubahan secara mendasar dalam kebiasaan masyarakat sehari-hari seperti perubahan terhadap pola pikir dan tingkah laku masyarakat sehari-harinya.

Semakin berkembangnya ilmu teknologi, memungkinkan masyarakat untuk lebih konsumtif dalam menggunakannya (Ngafifi, 2014). Saat ini dikalangan masyarakat telah banyak terjadi segala bentuk tindakan menyimpang seperti kenakalan remaja yang dilakukan anak-anak yang masih berada dibawah umur. Hal ini dikarenakan adanya faktor-faktor dari dalam dan luar dimana kebebasan pertama-tama dibatasi oleh faktor dari dalam baik fisik maupun psikis (Bertens, 1994).

Peraturan hukum yang berlaku di Negara Indonesia merupakan suatu peraturan yang wajib ditaati oleh seluruh warga-warga Negara Indonesia. sesuai ketentuan pasal 26 ayat (1) Undang - Undang Dasar Tahun 1945 (selanjutnya disebut dengan UUD 1945), menyatakan: "Yang menjadi warga negara ialah orang-orang bangsa Indonesia asli dan orang -orang bangsa lain yang disahkan dengan undang-undang sebagai warga negara".

Jika dilihat berdasarkan perspektif psikologi kerap ditemukan pada para remaja yang memiliki perilaku menyimpang dari norma hukum yang ada di Indonesia. Salah satunya dari perbuatan menyimpang yaitu tindak penganiayaan ini dilakukan oleh anak kepada orang tua diarea keluarga. Penganiayaan adalah tindak pidana yang dilakukan seseorang atau kelompok yang mengakibatkan luka memar (Firma Umar, 2017).

Penganiayaan memang sering terjadi dilingkungan masyarakat. Penganyaan ini bermmacam-macam mulai penganiayaan ringan sampai penganiayaan, penganiyaan berat bahkan menyebabkan kematian. Hal ini terjadi dipicu oleh faktor ekonomi, faktor lingkungan dan dalam kehidupan sehari-hari telah banyak terjadi tindak penganiayaan yang biasanya mayoritasnya dilakukan oleh laki-laki dan perempuan. Suatu tindak penganiayaan merupakan suatu perbuatan yang melanggar hak asasi manusia yang dimiliki oleh seseorang, diketahui akhir-akhir ini didalam lingkungan keluarga banyak dijumpai adanya suatu perbuatan menyimpang dari seorang anak kepada orang tua.

Perbuatan kejahaatan terhadap orang tua sampai saat ini masih terbilang indeksnya tinggi, hal tersebut dikarenakan sanksi yang berlaku berupa sanksi fisik yang akan dijatuhkan kepada seorang anak dibawah umur yang melakukan perbuatan yang menyimpang terhadap suatu norma hukum yang ada. Oleh karena iitu orang tua sangat dibutuhkan peranan dalam lingkungan keluarga untuk dapat memberikan kasih sayang, serta mendidik anak tersebut dengan tujuan agar seorang anak memiliki kepribadian yang baik terhadap orang lain. Berdasarkan Pasal 28A Undang-Undang Dasar 1945 ("UUD 1945”) yang berbunyi: "Setiap orang berhak untuk hidup serta berhak mempertahankan hidup dan kehidupanya" Dilanjutkan dengan pengaturan HAM Pasal 4 UU No. 39 tahun 199 tentang HAM. Penelitian terdahulu mengungkapkan bahwa setiap kejahatan yang dilakukan oleh anak harus tetap bertanggungjawab atas perilaku yang dilakukannya agar dia mendapatkan pembeajaran dan perubahan diri, hal ini menjadi pendidikan karakter bagi anak (Afifah, 2014). Penelitian kedua Anak yang melakukan tindak pidana tetap dimintai pertanggungjawabannya, ancaman pidana bagi anak yang melakukan suatu perbuatan yang melawan hukum ditentukan oleh Kitab Undangundang Hukum Pidana, namun penjatuhan pidananya ditentukan setengah dari maksimal ancaman pidana dari orang dewasa, sedangkan penjatuhan pidana seumur hidup dan pidana mati tidak diberlakukan terhadap anak (Pangemanan, 2015). Selanjutnya Hardiansyah, (2020) mengungkapkan Tindakan pidana yang diberikan kepada anak sebagai pelaku kejahatan kesusilaan secara berlanjut yakni dilaksanakan dengan tindakan berupa mengembalikan terdakwa kepada orang tuanya untuk dibina dan dididik, sehingga dalam penelitian ini lebih mendalami tentang sanksi yang diterapkan atau berlaku seorang anak dibawah umur yang melakukan tindak penganiayaan kepada orang tua kandung. Penelitian ini bertujuan untuk menganalisis pengaturan pemidanaan terhadap anak dibawah umur yang melakukan tindak pidana kepada orang tua dan

menjelaskan sanksi pemidanaan yang diberikan terhadap seorang anak yang melakukan tindak pidana penganiayaan.

\section{METODE PENELITIAN}

Penelitian ini didesain menggunakan penelitian hukum normatif atau kepustakaan dengan pendekatan perundang-undangan.Pada penelitian normatif mengkaji mengenai analisis pengertian-pengertian dalam 
hukum atau konsep-konsep dalam hukum, analisis asas dan sistem hukum, analisis norma hukum dan analisis keberlakuan hukum (Diantha, 2016). Data penelitian digunakan adalah Bahan hukum primer yaitu aturan hukum yang diurut secara sistematik terdiri dari perundang-undangan, sedangkan bahan hukum sekunder terdiri dari buku-buku, teks, prinsip-prinsip dan tulisan tentang hukum yang terkait pengaaniayaan.

\section{HASIL DAN PEMBAHASAN}

1. Pengaturan Pidana terhadap Anak yang Melakukan Tindak Pidana Penganiayaan Kepada Orang Tua Penerapan pemberlakuan pertanggungjawaban pidana haruslah didahului dengan perbuatan yang melawan hukum atau suatu kesalahan terlebih dahulu, dapat dikatakan bahwa sebelum seseorang dijatuhi pertanggungjawaban haruslah berdasarkan atas kesalahan dimana kesalahan seseorang tersebut menjadi dasar pokok diberikannya sanksi yang sesuai dengan kesalahannya sehingga keadilan akan dapat ditegakkan berdasarkan dengan kepastian hukum.

Menurut, Tirtaamidjaja, penganiayaan adalah rasa sakit yang ditimbulkan dengan cara sengaja kepada orang lain, tetapi jika rasa sakit yang di lakukan itu untuk menyelamtkan diri atau badan tidak disebut penganiayaan atau bisa disebut untuk menjaga diri (Leden, 2002). Penganiayaan yang dilakukan oleh anak kepada orang tua dapat dijatuhi hukuman dalam pasal 351 KUHP tentang penganiayaan namun dalam hal ini jika subjek hukumanya yaitu pelaku penganiayaan adalah anak dibawah umur maka terhadap pelaku diadili menggunakan hukum acara peradilan anak, diamana pengertian anak dalam peradilan anak adalah mereka yang masih berada dibawah umur.

Jadi penganiayaan oleh anak kepada orang tua dapat dikenakan pasal 351 KUHP JO Pasal 1 angka (3) Undang-Undang No. 11 tahun 2012 tentang peradilan anak. Jika ditinjau dalam perspektif Hak Asasi Manusia maka penganiayaan termasuk melanggar Pasal 28 A, $28 \mathrm{~J}$ angka (1) dan $28 \mathrm{~J}$ ayat (2). Pemidanaan dapat diartikan pemberian sanksi dan penetapan sanksi, kata "pidana" ini diartikan hukum dan "pemidanaan" sebagai penghukuman. Umumnya pidana dijatuhkan untuk pelaku kejahatan agar tidak lagi berbuat jahat orang lain takut melakukan kejahatan yang sama. Hukum pidana di Indonesia diatur dua jenis pemidanaan yaitu Pidana pokok yaitu pidana mati, penjara, kurungan dan denda. Sedangkan Pidana Tambahan terdiri dari: Pencabutan hak-hak tertentu, perampasan barang-barang tertentu dan pengumuman putusan hakim.

Penganiayaan oleh anak kepada orang tua adalah pelanggaran HAM yang wajib ditegakkan HAM menjadi salah satu hak dasar yang harus mendapatkan payung hukum sebagai dasar penegakan hukum yaitu pada Undang-Undang Dasar Republik Indonesia Tahun 1945 pada pasal 28A tentang hak untuk hidup dan penerapanya dilanjutkan pada pasal 351 tentang penganiayaan bahwa setiap orang berhak atas rasa aman dan kehidupan jika seorang anak melanggar hal tersebut tidak dapat dipidana anak tersebut karena di bawah umur, dalam hal ini anak tetap dikenakan sanksi pidana berdasarkan Undang-Undang Sistem Peradilan Pidana Anak yang dimana terkait pemidanaanya telah diatur sesuai hak asasi seorang anak dan psikologi anak agar tercapai tujuan pemidanaan tersebut.

\section{Sanksi Pidana Terhadap Anak yang Melakukan Tindak Pidana Penganiayaan Kepada Orang Tua}

N.E Algraa, ddkk Mengemukakan pengertian sanksi. Sanksi adalah: Pengukuhan, penguatan suatu Tindakan yang tanpa itu tidak sah menurut hukum. Dalam hukum pidana, hukuman alat pemaksa, selain dari hukuman, juga gunanya menaati ketetapan yang dijatuhkan dalam peraturan atau perjanjian, syarat yang ditentukan. Esensi sanksi, yaitu Hukuman dan Alat pemaksa.

Anak adalah generasi-generasi muda sebagai sumber daya manusia peran penting, yang memiliki ciri dan sifat khusus dan peran strategis. Anak membutuhkan pembinaan perlindungan untuk menjamin pertumbuhan dan perkembangan fisik, mental secara utuh selaras dan seimbang karena pada dasarnya orang tualah yang berperan penting dalam permasalahan ini. Dalam lingkungan kedudukan anak sebagai subjek hukum

ditentukan dari sistem hukum kepada anak didalam lingkungan masyarakat yang ada di status hukum dan termasuk tidak mampu atau di bawah umur, maksud tidak mampu ialah karena pertumbuhan fisik dan kedudukan akal sedang berkembang dalam diri anak tersebut (Hutahaean, 2013). 
Ancaman pidana yang dapat dijatuhkan terhadap anak yang melakukan penganiayaan ialah paling lama setengah dari ancaman pidana mati orang dewasa, yang di maksud dalam hal ini diancam pidana mati atau penjara seumur hidup maka karena itu ancaman pidana buat anak yaitu maksimal 10 tahun, dengan adanya ancaman tersebut berfokus membuat anak takut melakukan tindak kejahatan dan efek jera bagi anak.

Ada beberapa Pasal-pasal yang sesuai dengan unsur pidana penganiayaan yakni: Pasal 351 sampai 358, berdasarkan ketentuan pasal di atas jelas bahwa tindak penganiayaan tidak menimbulkan rasa sakit atau halangan untuk menjalankan pekerjaan jabatan dan pencarian, maka si pelaku dapat dikenakan pasal tentang penganiayaan. Tetapi jika korban penganiayaan tersebut menjadi bawaan si pelaku maka pidananya dapat ditambah sepertiga dan jika korban penganiayaan misalnya ibu atau si keluarga pelaku ditambah sepertiga maka tidak termasuk penganiayaan ringan. Berdasarkan ketentuan diatas, bisa kita simpulkan yang ditekankan ialah penganiayaan itu menyebabkan rasa sakit atau tidak dan mengakibatkan korban tidak dapat melaksanakan atau melakukan pekerjaan karena sakit yang dialaminya, namun tidak sampai berakibat luka berat maka penganiayaan itu dapat dipidana dengan undang-undang yang berlaku.

\section{SIMPULAN DAN SARAN}

\section{Simpulan}

Pengaturan pidana terhadap anak dibawah umur yang melakukan tindak pidana penganiayaan terhadap orang tua, diatur pada Sistem Peradilan Pidana Anak dalam hal ini anak tetap dapat dikenakan sanksi pidana namun juga bisa dikenakan sanksi berupa sanksi pembinaan oleh instansi terkait. Setiap sanksi dapat diterapkan berdasarkan atas perbuatan yang telah diperbuat oleh pelaku yang notabenenya adalah seorang anak, yang kedua sanksi pidana yang diberikan terhadap seorang anak dibawah umur yang melakukan tindak pidana penganiayaan terhadap orang tua tidak bisa dikenakan sanksi pidana seperti yang diatur dalam pasal 10 KUHAP namun terhadap kasus ini dapat dikenakan Undang-Undang Sistem Peradilan Pidana Anak yang mana sanksi yang dapat dijatuhkan yaitu tertera pada Undang-Undang Sistem Peradilan Anak. Pemidanaan Nya pun berbeda dengan pemidanaan biasa, dimana pemidanaan anak bertujuan untuk membina anak dan bukan terfokus pada efek jera bagi pelaku kejahatan.

\section{Saran}

Melalui penelitian ini diharapkan kepada lembaga aparat penegak hukum seharusnya dapat bertindak adil dalam setiap menyelesaikan disetiap perkara yang bertentangan dengan hukum, karena sejauh ini aparat dinilai lambat oleh masyarakat dalam penanganan masalah mengenai perkara anak. Contohnya bila pelakunya adalah anak pejabat maka aparat dengan cepat menyelesaikan kasus tersebut, berbeda dengan konteks pelakunya anak biasa aparat seharusnya bisa berlaku adil dan tegas menjalankan tugas dan prosedur serta undang-undang yang berlaku tanpa memihak dan tidak pandang bulu. Di dalam pemberian sanksi agar sanksi yang diberikan kepada anak tidak membuat moral anak rusak dan dan agar tujuan dari diadakan pemidanaan dapat terwujud. Kedua, kepada masyarakat dan orang tua sebaiknya lebih memberi banyak waktu dan kasih sayang serta arahan-arahan yang baik dan juga tidak membiasakan anak melihat adegan-adegan yang berperilaku kasar. Berikan bimbingan terhadap anak dengan halus dalam berbagai hal yang dialami oleh anak didalam keseharianya baik dalam lingkungan anak tersebut maupun di area masyarakat sekitarnya.

\section{DAFTAR PUSTAKA}

Afifah, W. (2014). Pertanggungjawaban Pidana Anak Konflik Hukum. DiH: Jurnal Ilmu Hukum, 10(19), 48-62.

Bertens, K. (1994). Etika Seri Filsafat. Pt. Gramedia.

Diantha, P. (2016). Metodologi Penelitian Hukum Normatif dalam Justifikasi Teori. Prenada Media Group.

Firma Umar, I. (2017). Penanganan Kasus Anak Korban Kejahatan Penganiayaan. Jurnal Supremasi, 12(1), 1689-1699.

Harahap, Z. (2002). Hukum Acara Peradilan Tata Usaha Negara. Rajawali Pers.

Hardiansyah, A. (2020). Pertanggungjawaban Pidana Terhadap Anak Sebagai Pelaku Kejahatan Kesusilaan Secara Berlanjut. 1(2), 78-92.

Hutahaean, B. (2013). Penerapan Sanksi Pidana Anak. Jurnal Yudisial, 6(1).

Leden, M. (2002). Tindak Pidana terhadap nyawa dan tubuh. Sinar Grafika. 
Ngafifi, M. (2014). Kemajuan Teknologi Dan Pola Hidup Manusia Dalam Perspektif Sosial Budaya. Jurnal Pembangunan Pendidikan: Fondasi Dan Aplikasi, 2(1), 33-47.

Pangemanan, J. B. (2015). Pertanggungjawaban Pidana Anak dalam Sistem Peradilan Pidana Indonesi. Jurnal Lex et Societatis, 3(1), 101-108. 